\title{
The position of women in the short stories, The Last Song and The Pot Maker, by TemsulaAo.
} Rashmi Naik

Guest Faculty, Bengaluru Central University, Bengaluru, India

\begin{abstract}
This article looks at how the northeastern literature presents the gender roles that are different from rest of the country using the works of TemsulaAo. The texts used here are The Pot Maker and The Last Song from her well known works 'These Hills Called Home: Stories from a War Zone'. These are the short stories set in the northeastern region of the country where the characters go through a number issues ranging from gender inequality to cruelty imposed due to insurgency.
\end{abstract}

Keywords-Gender roles, TemsulaAo, The Pot Maker, The Last Song.

The women in the world are often seen as the second sex (Simone De Beauvoir). It's not just in one or two counties, but throughout the human civilizations. Starting from the basic rights to live to various levels in the society. Women are given unequal access to education, unequal health care facilities to insufficient promotions and prohibitions of their basic rights. Starting from the oldest civilization, i.e., Greek, Roman, and Vedic age to the Modern day, from ancient day epics to present day literature and newspaper articles, there have been numerous cases that show women in Inferior (lesser) position.

TemsulaAo, a writer from Nagaland is known for her works, 'These hills called home' and 'Laburnum for my head'. These are a collection of short stories, where the essence of her stories lingers on the reader's mind through juxtaposing images that she weaves. We see the images of beauty that the nature possesses and the manifestation of the cruelty that a human/mankind can impose. The language is simple and the complex themes give rises to a labyrinth of emotions. In her stories, women are shown to be innately strong and wise through the protagonists of her stories mainly the mother and daughter, who also share a beautiful relation. And this aspect, marks a distinction between the stories from the north east to the stories across the country.

TemsulaAo in her short stories has tried to subvert the notion that women are the weaker section of the society, and shows that women are capable, more so by examining the characters, the domain and the position the women hold in the short stories of 'The last Song' and 'The Pot Maker'.

In these two stories, the first thing we notice is the absentee father or a passive fatherly figure. The bread winner of family is always assumed to be a man. But in
The Last Song, the father, Zhamben, dies when the protagonist of the story, Apenyo is nine months old and in The Pot Maker, the father of Sentila, Mesoba plays a passive role where he listens to his wife (henpecked) Arenla and does not assert his superiority. The women here play the active role in earning their daily wages, may it be working in the fields to grow food or the pot making or the art of weaving. TemsulaAo subverts the society's gender construction, where the male is given the masculine role and the female, a subservient role. In the stories we see women perform heavy chores and physically challenging tasks such as farming and carrying baskets of mud load uphill. And also, the women have their freedom to choose what they want to do. For instance, Apeno's mother Libeni, chooses not to marry against the wishes of her relatives, who assume that a man is required to protect and look after them. And Sentila chooses to become an accomplished pot maker like her mother, Arenla, despite the fact that pot making was less rewarding then weaving.

In the Greek literature, we see the worship of gods and goddesses. But there is a certain determined perfection in the male deity and fundamental imperfections in the female deity. The Greek god Zeus is seen as the virile masculine male and the Chief of the gods, whereas Hera, Queen of Zeus, is often portrayed through her jealousy and vengeful nature. Hence Aristotle says the women lack intelligence and rationality and so the decision making and the public affairs should be in the hands of men.

But here, in the stories we see that it is not the case. Both, Apenyo and Sentila are extremely intelligent and skilled individuals who learn the art of weaving and the art of pot making through observation of their mothers respectively. They make their individual choices and do not get coerced by their peers. Apenyo, who loved to sing, 
continues to sing despite the fact that she could only scream in her shrill voices at young age and as adult continues to sing even when the army is approaching. She here becomes the pillar of strength to the choir group, who inspired by the bravery of Apenyo, stay and start to sing. On the other hand, Sentila, wants to become the best pot maker, like her mother, against her mother's wishes, learns the art in secrecy and continues to do so till she becomes one of the best pot makers in her village. And here we also see how the mothers of these two young girls, make the decision themselves. Libeni decides to a single mother and builds a future for her daughter and herself. And Arenla, with her far sightedness who is well aware of the pains in pot making, advices her daughter an alternative source of income that could be more worthwhile and less extensive.

It is seen that the women in the north east have a certain amount of freedom that the women in the rest of the country were deprived of. We see that the choice of Libeni is accepted and also the fact that it was the family members who tried to get her remarried. Where as in most other places, we see a widowed woman is excluded from the society. Before independence she had to committee sati, deprived of her femininity, symbolically castrated or lived in destitution and that never changed. Even today, a widow of a farmer is not considered the owner of the land her husband owned (Nero's Guest by P. Sainath). In the last song, we see the land is owned by Libeni and becomes the primary source of her income. She tills the land and grows her own vegetables.

The analogy, the freedom to occupation can be further extended to Arenla, who does pottery and weaving, which is mostly constructed as the man's work due to the physical and mental exhaustion. Pottery that was revered as a man's job, Arenla does it with ease. She excelled at the art of pot making and the art of weaving.

The life of north-eastern tribal's is told through the eyes of TemsulaAo, through her stories. Though there is a sense of gender neutrality where men and women are given equal position, women are still caught in the traditional customs where they suffer. For example, in the Last song, the elders discuss what has to be done with the bodies left after the Black Sunday. The villagers argue that though they have embraced Christianity, they still are the tribal's of the Naga, and the people who died in an unfortunate way should be buried out of the village without a tombstone. It is to be seen that the unfortunate ones were violated and charred to death while the rest were shot to death.

There is a shift in the Pot Maker, where Mesoba is caught in a situation where he is ridiculed as an incompetent husband and father for listening to his wife and not letting the family business of pot making flourish. $\mathrm{He}$ is caught between the logic and the practical idea of the people. There is a construction of gender through social relations and the roles they play. Mesoba is required to do things that would benefit the society rather than his own home. We see that the roles given to men are socially and culturally determined and influenced by their customs, beliefs and institutional practices. And the societies of north east are seen as patriarchal society where men dominate and control resources and women. (Ruth Lalsiemsang Buongpui, Gender Relations and the Web of Traditions in Northeast India)

A man is seen as the norm and the rule, and a woman is a derivation and included in man, says the religion (Adam and Eve, the Shakti and so on). And hence men are given the power to define, interpret, judge and represent the world in their own terms while women are to be defined, interpreted and judged and represented by the men (V. Geeta). In the Pot Maker, we see that the village elders call upon Mesoba to know about the house affairs. Though the elders are aware that it is Arenla who refuses to pass on the knowledge of pot making to Sentila, and it is her they have to question, Mesoba is called upon to play the role of a patriarch, a male head. But as the reader we know that the power at home lies in the hands of Arenla.

Women are considered lesser due to the different in genitalia, (V. Geetha, Gender, 11). They are seen as the site where fights of identity, power, oppression and resistance are often fought on. In the story The Last Song, we see that the army tries to exert their power by oppressing the defiance of Apenyo who does not recognise the army as a formidable force to reckon with by sexually assaulting her. Women, across cultures are seen as the culture bearers and hence have their bodies tied to national identities. For that reason, Apenyo is doubly oppressed on the name of gender and the community. And this mechanism serves the dual function of subordination and violation of land through women. And Libeni, who jumps in to save Apenyo, has the same fate. As an act of resistance, Apenyo continues to hum, and this hum brings the downfall of their perpetrators. The captain of the troop at the end is seen in an insane asylum. What's interesting here is the fact that Apenyo though seen as the powerless, has the power to defy the army captain. She brings courage with her to sing in the chaos. Even after her death, the captain is seen to haunted by her and there is a hum left in the air that seems to have an eerie nature around it.

That being said, till the recent times, women were not considered the natural heirs to their father's property and a woman who had wealth given by her family was considered as StriDhan (as Manusmriti puts it and Hindu 
marriage act till it got changed.) and it would have to be divided equally among the living heirs may it be male or female. In the story, The Pot Maker, we see that the Family has been a pot maker for generations and Arenla inherited this art from her mother and Sentila from Arenla. In The Last Song, though Apenyo got her singing talent from her father, it is a grandmother who continues the art of storytelling to keep Apenyo's singing alive. In both the stories, we see that it's the women who sing the folk songs. And this can also be assumed to be passed down to them through their mothers. Hence, the women become the heirs to the gifts passed down from their parents.

The history is written by men. Only a negligible amount of historians are women who get recognised in mainstream. (Romila Thapar among Guha, Majumdar and Habib). And here we have the old lady who sings the story of Apenyo and the Black Sunday. The old lady becomes an important figure by passing down and educating the coming generation. In gurukul system, gurus and students were male; here we have the old lady who didn't differentiate student on their gender but passed on her knowledge for the sake of knowledge. And rather than the written tradition, we see women propagating the oral traditions. The last song the old lady carries, becomes a symbol of resistance and bravery, a girl little over eighteen had shown.

TemsulaAo writes in the period where the north eastern region has been the battleground for a long time. There are a lot of tensions such as the identity crisis, communal tension and the fear of oncoming battles. Hence we see the violence, suffering, terror, the hopelessness of the situations in her stories. But here in her stories we also see that woman characters seem to get stronger with every passing moment and bring with them courage, hope and strength. We see that the role women play in the stories has been a dynamic and a powerful one.

\section{REFERENCES}

[1] Ao, Temsula. The Pot Maker, 'These Hills Called HomeStories from a War Zone', New Delhi, Penguin Books India with Zubaan Books, 2006.

[2] Ao, Temsula. The Last Song, 'These Hills Called HomeStories from a War Zone', New Delhi, Penguin Books India with Zubaan Books, 2006.

[3] Geetha, V. 'Theorizing feminism', Calcutta, 2002.

[4] Sarma, Prabalika. 'The Portrayal of Violence in the Writings of TemsulaAo and Easterine Iralu' The Criterion, An International Journal in English, April 2014, Vol. V, No. 2.

[5] Buongpui, Ruth Lalsiemsang. 'Gender Relations and The Web of Traditions in Northeast India', The NEHU Journal, Vol XI, No. 2, July 2013.
[6] Singh, Kumam Davidson. 'Reading the short stories of TemsulaAo: Looking Towards an Alternate-Narrative,' Article on e-pao.net, May 15, 2012.

[7] Gogoi, Sikhamoni. 'An Ecofeminist Reading of TemsulaAo's Laburnum for My Head', the Criterion, an International journal in English, March 2012, Vol. III, No.1. 